$\underline{\text { Article }}$

\title{
Spectrophotometric Determination of Uranium Using 2-(2- Thiazolylazo)-p-Cresol (TAC) in the Presence of Surfactants
}

\author{
Leonardo Sena Gomes Teixeira ${ }^{\mathrm{a}}$, Antonio Celso Spínola Costa ${ }^{\mathrm{a}}$, Sérgio Luís \\ Costa Ferreira $^{\text {a }}$, Maria de Lourdes Freitas ${ }^{\text {b, Marcelo Souza de Carvalho }}{ }^{\text {b }}$ \\ ${ }^{\mathrm{a}}$ Instituto de Química, Universidade Federal da Bahia, 40170-290 Salvador - Ba, Brazil \\ ${ }^{\mathrm{b}}$ Instituto de Engenharia Nuclear, CNEN, 21945-970 Rio de Janeiro - RJ, Brazil
}

No presente trabalho apresenta-se um método seletivo e sensível para rápida determinação de urânio usando o 2-(2-Tiazolilazo)-p-Cresol (TAC). O TAC reage com o urânio(VI) em pH 6,5 formando um complexo estável por pelo menos $3 \mathrm{~h}$. Brometo de N-cetil-N,N,N-trimetil amônio (CTAB) e triton X-100 foram usados para aumento da sensibilidade e solubilidade do sistema respectivamente. $\mathrm{O}$ método permite a determinação de urânio na faixa de 0,30 a $12,0 \mu \mathrm{g} \mathrm{mL}^{-1}$ com absortividade molar estimada em $1,31 \times 10^{4} \mathrm{~L} \mathrm{~mol}^{-1} \mathrm{~cm}^{-1}$ e limite de detecção de $26 \mathrm{ng} \mathrm{mL}^{-1} \mathrm{em}$ $588 \mathrm{~nm}$. O uso do ácido 1,2-ciclohexilenodinitrilo tetraacético (CyDTA) como agente mascarante aumenta a seletividade do reagente para a determinação de urânio. O método proposto foi aplicado para determinação de urânio em água drenada de mina onde a precisão (R.S.D. < 2\%) e exatidão obtidas foram satisfatórias.

A sensitive and selective spectrophotometric method is proposed for the rapid determination of uranium using 2-(2- Thiazolylazo)-p-Cresol (TAC). The reaction between TAC and uranium (VI) is instantaneous at $\mathrm{pH} 6.5$ and the absorbance remains stable for over $3 \mathrm{~h}$. N-cetyl-N,N,N-trimethylamonium bromide (CTAB) and triton X-100 are used for increasing the sensitivity and solubility of the system respectively. The method allows the determination of uranium in the range from 0.30 to $12.0 \mu \mathrm{g} \mathrm{mL}^{-1}$ with a molar absorptivity of $1.31 \times 10^{4} \mathrm{~L} \mathrm{~mol}^{-1} \mathrm{~cm}^{-1}$ and features a detection limit of $26 \mathrm{ng} \mathrm{mL}^{-1}$ at $588 \mathrm{~nm}$. The selectivity of the reagent was improved by the use of (1,2-cyclohexylenedinitrilo) tetraacetic acid (CyDTA) as masking agent. The proposed method has been successfully applied to the determination of uranium in mine drainage waters. The precision (R.S.D. $<2 \%$ ) and the accuracy obtained were satisfactory.

Keywords: 2-(2-Thiazolylazo)-p-Cresol, spectrophotometry, uranium determination, surfactants

\section{Introduction}

Uranium mining and milling operations, as well as the mining of some ordinary metal ores, produce large quantities of low activity wastes in both liquid and solid forms. The management of these wastes has been a concern in many countries triaging about typical problems like groundwater contamination, proximity of communication to populated areas, and besides lack of funds, limited resources make management of such waste volumes difficult $^{1}$.

The determination of uranium by molecular spectrophotometry is important in analytical chemistry. Atomic spectrometry methods have found little application for the determination of uranium mainly due to its high spectral background and the low sensitivity attainable due to the high thermal stability of uranium oxides ${ }^{2,3}$.

Thiazole azo compounds have attracted much attention as they are sensitive chromogenic reagents in addition to being important complexing agents. They have been used for spectrophotometric and extraction- photometric determination of many metal ions. These dyes have been useful in the spectrophotometric determinations due its good selectivity and sensitivity over a wide range of $\mathrm{pH}$ and because they are relatively easy to synthesize and purify ${ }^{4-7}$.

The reagent 2-(2- Thiazolylazo)-p-Cresol (TAC) is an easily accessible heterocyclic azo-dye which has attracted considerable attention in the literature. It was first prepared 
by Kanenina ${ }^{8}$ and its application as a spectrophotometric reagent have been studied ${ }^{9}$. In our laboratory TAC has been used for spectrophotometric determination of vanadium ${ }^{10}$, titanium $^{11}$, lead ${ }^{12}$, indium ${ }^{13}$ and nickel ${ }^{14}$.

Application of micelles in analytical chemistry involves the beneficial alteration of metal ion-ligand complex spectral properties via surfactant association. The utility of micelles in spectroscopic measurements derived from several possible effects upon the system of interest, as an example, the formation of a ternary complex with concomitant shifts in the analytical wavelength ${ }^{15}$. In this way the sensitivity and the selectivity of numerous analytical reactions can be improved with the addition of certain surfactants. An another benefit of the presence of a surfactant in the system is the capacity to solubilize an insoluble complex and/or ligands ${ }^{16,17}$.

In this paper a simple and accurate method to determine uranium in mine drainage water samples is described using TAC as a spectrophotometric reagent. In the proposed method N-cetyl-N,N,N-trimethylamonium bromide (CTAB) and triton X-100 are used for increasing the sensitivity and solubility of the system respectively. The results were evaluated by determining uranium using an $\mathrm{X}$-ray fluorescence method ${ }^{18}$ and they agreed within a $95 \%$ confidence level.

\section{Experimental}

\section{Reagents}

All reagents used were of analytical grade.

Uranium stock solution $\left(1000 \mu \mathrm{g} \mathrm{mL}^{-1}\right)$. Prepared by dissolving $1.7823 \mathrm{~g}$ of uranyl acetate (Merck) in $1 \mathrm{~mol} \mathrm{~L}^{-1}$ nitric acid and diluting to volume with nitric acid solution in a $1000 \mathrm{~mL}$ volumetric flask.

2-(2- Thiazolylazo)-p-Cresol (TAC) solution (0.04\%). Prepared by dissolving $0.080 \mathrm{~g}$ of TAC (Aldrich) in 200 $\mathrm{mL}$ of ethanol.

Complexing solution. Prepared by suspending $50 \mathrm{~g}$ of 1,2-cyclohexylenedinitrilo tetraacetic acid (CyDTA, Merck), $5 \mathrm{~g}$ of sodium fluoride (Merck) and $130 \mathrm{~g}$ of sulfosalicylic acid (Carlo Erba) in $500 \mathrm{~mL}$ of demineralized water, neutralizing to $\mathrm{pH} 6.5$ with sodium hydroxide and diluting to $1 \mathrm{~L}$.

$\mathrm{N}$-cetyl-N,N,N-trimethylamonium bromide (CTAB) solution $\left(0.05 \mathrm{~mol} \mathrm{~L}^{-1}\right)$. Prepared by dissolving $2 \mathrm{~g}$ of CTAB (Merck) in $100 \mathrm{~mL}$ of demineralized water.

Triton $X-100$ solution $\left(0.15 \mathrm{~mol} \mathrm{~L}^{-1}\right)$. Prepared by dissolving $2 \mathrm{~g}$ of triton $\mathrm{X}-100$ (Aldrich) in $100 \mathrm{~mL}$ of demineralized water.

Triethanolamine buffer ( $\mathrm{pH}$ 6.5). Prepared by dissolving $149 \mathrm{~g}$ of triethanolamine (Merck) in $800 \mathrm{~mL}$ of demineralized water, neutralizing to $\mathrm{pH} 6.5$ with hydrochloric acid and diluting to $1 \mathrm{~L}$ with demineralized water.

\section{Apparatus}

Spectrophotometric measurements were made in a Cary 1E UV-visible spectrophotometer (Varian) with 1.00-cm glass cells. The $\mathrm{pH}$ measurements were performed with an ANALYSER $300 \mathrm{pH}$ meter. A Rigaku-B3 wavelength dispersive $\mathrm{X}$-ray fluorescence spectrometer, with a rhodium tube operated at $40 \mathrm{kV}$ and $30 \mathrm{~mA}$, a LiF crystal and a scintillation counter were used.

\section{Procedure}

Into a $25 \mathrm{~mL}$ standard flask, transfer a portion of the solution containing uranium in the range from 7.50 to 300.0 $\mu \mathrm{g}, 5.0 \mathrm{~mL}$ of complexing solution, $1.0 \mathrm{~mL}$ of TAC solution, $1 \mathrm{~mL}$ of triton $\mathrm{x}-100$ solution, $1 \mathrm{~mL}$ of CTAB solution and $5.0 \mathrm{~mL}$ of buffer solution. Dilute to the mark with demineralized water and measure the absorbance at $588 \mathrm{~nm}$ in a 1-cm cell, against a blank prepared in the same way but without uranium.

\section{Results and Discussion}

\section{Characteristics of uranium(VI)-TAC complex}

Under the conditions used, uranium(VI) ions and TAC form a blue complex with an absorption maximum at 588 $\mathrm{nm}$. The reaction between TAC and uranium(VI) is rapid and the complex formed is stable for at least $3 \mathrm{~h}$. The use of CTAB promotes an increase in the absorbance signal and as a result the determination sensitivity is increased (Fig. 1). In the presence of CTAB, uranium-TAC complex has a low solubility in water, which can be overcome by adding triton X-100.

\section{Effect of the $\mathrm{pH}$}

The $\mathrm{pH}$ effect on the uranium(VI)-TAC system shows a maximal and constant absorbance at $\mathrm{pH}$ ranging from 6.0 to 7.0. A triethanolamine buffer was used as $\mathrm{pH}$ controler.

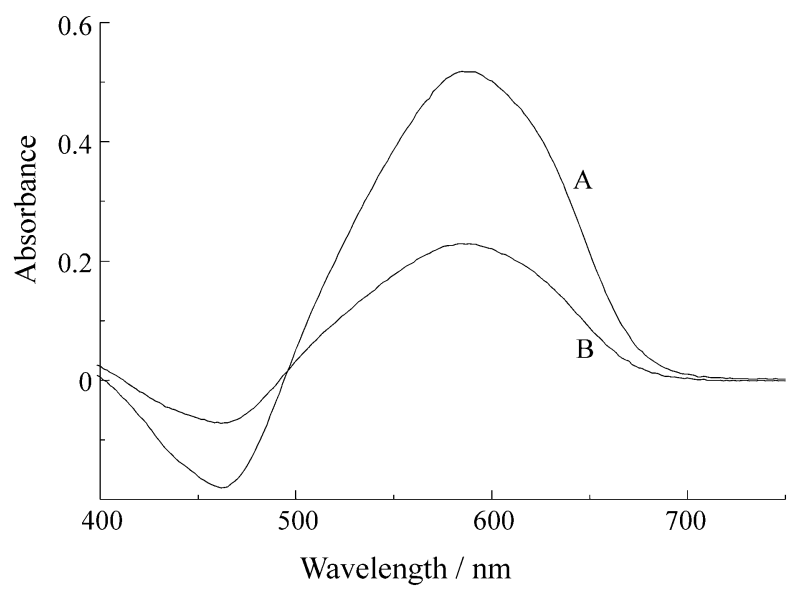

Figure 1. Spectra of uranium(IV)-TAC complex. (A) in presence of 2.0 x $10^{-3} \mathrm{~mol} \mathrm{~L}^{-1}$ of CTAB; (B) in absence of CTAB. [U] $=10.0 \mu \mathrm{g} \mathrm{mL}^{-1}$; $\mathrm{pH}=6.5$. 
The effect of the buffer concentration on the uranium(VI)TAC complex was studied and according to the results no effect was observed in the absorbance signal within triethanolamine concentration range from 0.10 to $0.60 \mathrm{~mol}$ $\mathrm{L}^{-1}$. Thus, a concentration of $0.2 \mathrm{~mol} \mathrm{~L}^{-1}$ was chosen for the procedure.

\section{Effect of the amount of Surfactants}

The results showed that triton X-100 must be present in the system in a minimum concentration of $1.2 \times 10^{-3} \mathrm{~mol}$ $\mathrm{L}^{-1}$ to avoid precipitation. When this surfactant is present in the range from $3.0 \times 10^{-3}$ to $6.0 \times 10^{-3}$ no effect was observed on the absorbance signal. The concentration of $6.0 \times 10^{-3}$ mol L ${ }^{-1}$ was chosen for the procedure.

When CTAB is present in a minimum concentration of $2.0 \times 10^{-3} \mathrm{~mol} \mathrm{~L}^{-1}$, the absorbance signal is maximal and constant. CTAB does not affect the absorbance signal in the concentration range from $2.0 \times 10^{-3}$ to $3.0 \times 10^{-3} \mathrm{~mol} \mathrm{~L}^{-1}$. Therefore, the concentration of $2.0 \times 10^{-3} \mathrm{~mol} \mathrm{~L}^{-1}$ was chosen for the procedure.

\section{Effect of the order of addition of the reagents on the complex formation}

The results showed that the absorbance signal is independent of the order of mixing the components. Then the reagents can be added in any order.

\section{Composition of uranium(VI)-TAC Complex}

A study of the complex composition by mole ratio method showed that TAC, like $\mathrm{TAR}^{7}$, forms a 1:1 complex, with the uranyl ion.

Under the conditions employed $1.0 \mathrm{~mL}$ of $0.04 \%$ TAC solution was required to obtain maximal and constant absorbance signal when $12 \mu \mathrm{g} \mathrm{mL}^{-1}$ of uranium were used.

\section{Effect of interfering ions}

TAC is not a selective reagent for uranium determination. However the very useful mixture of fluoride, CyDTA and sulfosalicylic acid for masking interfering ions increases the selectivity of the reaction. This complexing solution $(5 \mathrm{~mL}$ per $25 \mathrm{~mL}$ ) causes a $4 \%$ decrease in the absorbance. This mixture was used previously in the uranium determination with $\mathrm{TAR}^{7}, \mathrm{PAR}^{19}, \mathrm{PADAP}^{20}$ and Br-PADAP ${ }^{21}$.

To study the effect of various metals on the determination of uranium with TAC, a solution containing both uranium and the foreign metal was treated according to the procedure. The reaction selectivity was investigated by determining $100.0 \mu \mathrm{g}$ of uranium in the presence of 1000 $\mu \mathrm{g}$ of other ions using the mixed CyDTA, fluoride and sulfosalicylic acid complexing solution. The tolerance limit was taken as $\pm 3 \%$ change in absorbance. It was found that for these amounts, $\mathrm{Al}(\mathrm{III}), \mathrm{Ba}(\mathrm{II}), \mathrm{Be}(\mathrm{II}), \mathrm{Ca}(\mathrm{II}), \mathrm{Cd}(\mathrm{II})$,
Table 1. Uranium determination in mine drainage waters.

\begin{tabular}{lcc}
\hline Sample & X-ray $\left(\mu \mathrm{g} \mathrm{mL}^{-1}\right)$ & This method $\left(\mu \mathrm{g} \mathrm{mL}^{-1}\right)$ \\
\hline Situ M-0750 & $5.93 \pm 0.51$ & $5.72 \pm 0.28$ \\
Situ M-241 & $7.37 \pm 0.54$ & $6.99 \pm 0.18$ \\
Mine digging & $9.78 \pm 0.47$ & $9.59 \pm 0.24$ \\
\hline
\end{tabular}

$\mathrm{Co}(\mathrm{III}), \mathrm{Cr}$ (VI), $\mathrm{Cu}(\mathrm{II}), \mathrm{Fe}(\mathrm{III}), \mathrm{Hg}(\mathrm{II}), \mathrm{Mg}(\mathrm{II}), \mathrm{Mn}(\mathrm{II})$, $\mathrm{Mo}(\mathrm{VI}), \mathrm{Sn}(\mathrm{IV}), \mathrm{Sr}(\mathrm{II}), \mathrm{Th}$ (IV), W(VI) did not interfere, but $\mathrm{Ni}(\mathrm{II}), \mathrm{Cr}(\mathrm{III}), \mathrm{V}(\mathrm{V}), \mathrm{Zr}$ (IV) interfered. Chloride, bromide, iodide, sulfate, nitrate, carbonate, acetate and fluoride did not interfere.

Application

In the proposed procedure, Beer's law is obeyed from 0.300 to $12.0 \mu \mathrm{g} \mathrm{mL}^{-1}$, with a molar absorptivity of $1.31 \mathrm{x}$ $10^{4} \mathrm{~L} \mathrm{~mol}^{-1} \mathrm{~cm}^{-1}$ with a coefficient of variation of $1.72 \%(n$ $=20$ ) and a detection limit of $26 \mathrm{ng} \mathrm{mL}^{-1}$ (99.7\% confidence level). The calibration curves were made as described in the experimental procedure and good correlation coefficients $(\mathrm{R}=0,9999)$ were found.

The proposed procedure was applied for uranium determination in mine drainage waters. The samples were collected in situ from the Poços de Caldas uranium mine. The results obtained were compared with those obtained by $\mathrm{X}$-ray fluorescence method where uranium was extracted using a polyurethane foam as the salicylate complex at $\mathrm{pH}$ 4.0 and measured directly on the solid extractor by XRF as previously described ${ }^{18}$. The results are shown in the Table 1. For the means of three determinations on each of the three samples there is no significant difference at the $95 \%$ confidence level between both methods.

\section{Conclusions}

The method using TAC as spectrophotometric reagent to determine uranium in the presence of CTAB and triton $\mathrm{X}-100$ is selective, rapid and simple. The uranium-TAC complex is stable and the determination sensitivity is comparable to other analytical methods. This method was successfully applied to determine uranium in mine drainage waters and the results showed good agreement with XRF methods, and the method involves less sophisticated instrumentation.

\section{Acknowledgements}

The authors acknowledge the financial support from CNPq, FINEP and CAPES.

\section{References}

1. International Atomic Energy, In The Principles of Radioactive Waste Management; Safety Series, No 111-F; Vienna, 1995. 
2. Moore, G.L. In Introduction to Inductively Coupled Plasma Atomic Emission Spectrometry; Elsevier; Netherlands, 1989.

3. Kirkbright, G.F.; Sargent M. In Atomic Absorption and Fluorescence Spectroscopy; Academic Press; London, 1977.

4. Hovind, H.R. Analyst 1975, 100, 769.

5. Shurupova, T.I.; Ivanov, V.M. Zh. Analit. Khim. 1976, $31,2162$.

6. Navratil, O.; Frei, R.W. Anal. Chim. Acta 1970, 52, 221.

7. Sommer, L.; Ivanov, V.M. Talanta 1967, 14, 171.

8. Kanenina, N. Kanazawa Daigaku Yakugakubu Kenkya Nempo 1959, 9, 27. Chem. Abstr. 54, 4541g.

9. Sommer, L.; Langová, M.; Kuban, V. Colln. Czech. Chem. Commum. 1976, 41, 1317.

10. Teixeira, L.S.G.; Spinola Costa, A.C.; Queiroz, A.S.; Amorim, A.M.M.; Bomfim, O. N.; Ferreira, S.L.C. Mikrochim. Acta 1998, 129, 103.
11. Ferreira, S.L.C.; Spinola Costa, A.C.; Andrade, H.A.S. Mikrochim. Acta 1993, 111, 119.

12. Ferreira, S.L.C.; Andrade, M.G.M.; Lopo, I.P.; Spinola Costa, A.C. Anal. Lett. 1991, 24, 1675.

13. Ferreira, S.L.C.; Spinola Costa, A.C.; Andrade, H.A.S. Microchem. J. 1991, 44, 63.

14. Ferreira, S.L.C. Talanta 1988, 35, 485.

15. McIntire, G.L. Crit. Rev. Anal. Chem. 1990, 21, 257.

16. Fan, Y.X.; Zheng, Y.X. Anal. Chim. Acta 1993, 281, 353.

17. Pavón, J.L.P.; Cordero, B.M. Analyst 1992, 117, 215.

18. Carvalho, M.S.; Domingues, M. de L.F.; Mntovano, J.L.; Filho, E.Q.S. Spectrochimica Acta Part B, in printed.

19. Florence, T.M.; Farrar, Y. Anal. Chem. 1963, 35, 1613.

20. Florence, T.M.; Johnson, D.A.; Farrar, Y.J. Anal. Chem. 1969, 41, 1652.

21. Johnson, D.A.; Florence, T.M.Anal. Chim. Acta 1971, 53,73 .

Received: January 5, 1999

FAPESP helped in meeting the publication costs of this article 